\title{
Niezwykłe i piękne rozważania nad tożsamością
}

\author{
Krystyna Kardyni-Pelikánová (Brno)
}

Putzlacher, Renata: W kawiarni Avion, której nie ma. Český Těšín: wyd. Spolek - Towarzystwo Avion, 2013. 180 s. ISBN 978-80-903424-5-3.

Putzlacher-Buchtová, Renata: V kavárně Avion, která není. Přel. Michael Alexa. Český Těšín: nakl. Spolek Towarzystwo Avion, 2016. 192 s. ISBN 978-80-903424-6-0.

Przed trzema laty ukazała się oryginalna, starannie - wręcz pięknie - wydana książka odznaczonej kilkoma już nagrodami poetki zaolziańskiej (autorki ośmiu tomików poetyckich), z wykształcenia polonistki, wykładowcy literatury polskiej w Uniwersytecie imienia Masaryka w Brnie, dr Renaty Putzlacher-Buchtovej $W$ kawiarni Avion, której nie ma (2013). Autorka zyskała za nią nominację do Angelusa - nagrody literackiej przyznawanej pisarzom środkowoeuropejskim. Niedawno wyszła bliźniacza, czeska wersja tego tomu w thumaczeniu Michaela Alexy $V$ kavárnĕ Avion, která neni (2016). Utwór ten stanowi pod wieloma względami pomost (a pojęcie mostu odgrywa w nim niezmiernie doniosłą, symboliczną rolę) „między dawnymi a nowymi laty”.

Takim pomostem jest nie tylko podjęcie tematyki tożsamości obszarów przejściowych, niesłusznie często degradowanych do kategorii „peryferii” oddalonej od „centrum” kulturalnego o lata świetlne (mówiąc półżartem: wiadomo przecież, iż Józef Piłsudski porównywał Polskę do obwarzanka twierdząc, że co w niej najlepszego - to na obrzeżach...). Pomostem jest również stworzenie przez dr Putzlacher oryginalnej formy, w którą problematykę ową obleczono. Zacznijmy od tej ostatniej.

Autorka, jak sama w tekście oznajmia, sięgnęła po prastarą, bo wywodząca się z czasów antycznych, formę silva rerum dobrze literaturze polskiej znana, opisywaną przez wybitnych literaturoznawców, jak Stefania Skwarczyńska (Kariera form rodzajowych bloku silva [w tejże:] Wokót teatru i literatury. Warszawa, 1970) czy Ryszard Nycz (Sylwy wspótczesne. Problem konstrukcji tekstu. Wrocław, 1984). Nazwa silva (las) określa zbiór tekstów różnorodnych; jej alternatywnymi nazwami bywały miscellanea, varia, czy hortus - ogród, formy, w których rządzi zasada różnorodności, (np. pamiętny Wacława Potockiego Ogród, ale nieplewiony, bróg, ale co krok to inszego zboża, kram rozlicznego gatunku... rzeczy, powieści, przygody, podobieństwa, przyktady, które jeśli nie byty, być mogty w obojej ptci, w róznych stanach żywota $i$ wieku ludzkiego... sa $i$ żarty z podufatymi bez sarkazmów przyjacioty; zbiór ten z 1660 roku pochodzacy wydany został drukiem dopiero w r. 1907.

Mówiąc silva rerum najczęściej jednak mamy w pamięci księgi-zapiski, kroniki rodzinne. Gatunek ten rozpowszechnił się w Polsce szczególnie po najeździe szwedzkim i zniszczeniach, jakich przyrównana przez Sienkiewicza do potopu nawałnica szwedzka dokonała w Polsce w XVII wieku, nie oszczędzając i drukarń. Księgi typu silva rerum pisano wówczas po dworkach szlacheckich dla upamiętnienia wydarzeń rodzinnych, sąsiedzkich, państwowych, ale dołączano w nich i własne lub zasłyszane czy krążące w podaniu ustnym przeróżne utwory, choć nie brakło i przepisów różnego rodzaju.

Księgi owe ocenia się dziś jako „wcieloną procesualność", oddająca chaos doświadczenia, są bowiem utworami niefabularnymi, niefikcyjnymi, o kompozycji amorficznej. Zasadą estetyczną, która nimi rządzi jest zasada polimorficznej varietas-różnorodności, jak wykazała to już S. Skwarczyńska. Varietas ową unaocznia dziś heterogeniczność tworzywa, eksponowana (co szczególnie u dr Putzlacher rzuca się w oczy) poprzez łączenie słowa $\mathrm{z}$ różnorodnymi ujęciami graficznymi. Ale omawiana księga o Avionie nie 
ma w sobie nic przypadkowego. Pozorne nieuporządkowanie jest rozmyślne: ma za zadanie przywołać jedynie pewne konwencje gatunkowe, by nadać im jednakże jak najbardziej własne, należące do autorki, oryginalne, wciągające czytelnika oblicze. Te stare encyklopedyczne formy poetka zaolziańska powołała do życia tylko po to, by tym silniej zamanifestowało się jej własne nachylenie liryczno-poetyckie, własny, nowy ogląd rzeczywistości. I w tym momencie właśnie przejawiła się druga obok varietas, od dawna wymieniana zasada sylwiczności: jest nią scalająca aktywność podmiotu, który pomimo improwizacyjności ukształtowania konsekwentnie ukazuje obszar życia wyznaczony horyzontem intelektualnym nadawcy, czyli własnym. Książka Renaty Putzlacher-Buchtovej stała się tak oryginalną opowieścią o własnej świadomości, a jednocześnie ciekawym zapisem przejściowości, kiedy to człowiek znajduje się w przedziwnej sytuacji: już nie tu, ale i jeszcze nie tam - i to zarówno w przestrzeni, jak i w czasie, w kulturze.

Proces przejściowości uświadamiano sobie w literaturze już od początku XX wieku, narastał w międzywojniu, widoczny jest i dziś. Literatura polska odpowiedziała na owo zjawisko różnymi formami niefabularnymi, niefikcyjnymi, których typowymi przykładami mogą być wybrane na chybił-trafił Charaktery Zofii Nałkowskiej czy późniejsze od nich utwory Marii Kuncewiczowej typu jej Przezroczy czy Natury.

A wszak odwołanie się do starej formy silva to tylko jedna strona narracji o kawiarni Avion Renaty Putzlacher-Buchtovej. Jest bowiem i strona druga, jak najbardziej nowoczesna, związana ze zmianami cywilizacyjnymi, pociagającymi za soba zmiany w ludzkiej percepcji, w odbiorze sztuki, nauki, świata. Po wszystkich dotychczasowych wynalazkach i przemianach żyjemy dziś, czy chcemy tego, czy nie, w kulturze obrazkowej. Owe hybrydy mowy, pisma i obrazka, „słowobrazy” czy „teksty wizualne”, będące „współdziałaniem technologii, człowieka i literatury" (to określenia praskiego teoretyka literatury i krytyka literackiego Karela Pioreckiego) są formami pogranicznymi i budzą coraz większą ciekawość, dostają się też do centrum zainteresowań pisarzy, czytelników, a w kon- sekwencji i badaczy literatury. Zainteresowanie owo zaś rośnie, w miarę jak formy kanoniczne coraz częściej wypadają z wysoko artystycznego obiegu. I właśnie utwór $W$ kawiarni Avion... jest takim, godnym uwagi, „tekstem wizualnym”, „dziełem synkretycznym”, które rozwija kreatywność odbiorcy zmediatyzowanymi formami funkcjonowania słowa, zmienia dawny kod komunikacji dzięki zamieszczonej obok słowa bogatej, starannie dobranej ikonografii, wprowadza elementy gry komunikacyjnej, prowokuje wreszcie do rozważań nad istota przesłania książki. A przesłaniem owym jest głęboka refleksja nad sednem tożsamości ludzi obszarów przejściowych. Do takich obszarów należy zarówno Zaolzie (z perspektywy czeskiej: české Těśinsko), jak i obszar zamieszkały przez oba nasze (i nie tylko) narody, zwany Europą Środkową.

Mimo dziś już niezmiernie obfitej literatury przedmiotu wciąż jeszcze dyskutuje się o tym, czy Europa Środkowa jest tylko konstrukcją myślową, „okolicznościowym” pojęciem terytorialnym, utworzonym dla przypomnienia czy wręcz uświadomienia Zachodowi, że ten obszar geograficzny nie należy do Europy Wschodniej, lecz jest anektowana po II wojnie światowej przez Związek Sowiecki na skutek postanowień Jałty częścią Europy Zachodniej, czy też jest to rzeczywisty, odrębny region, rozciągający się między dwoma mocarstwami: rosyjskim i niemieckim, region dość autonomiczny kulturalnie, posiadający własne znaki dystynktywne, choć ciążący ku Zachodowi. Czyli: czy jest to jakaś całość modelowa i typologiczna o własnym wzorcu kulturowym (a więc „wspólnota”), czy tylko przypadkowo formowana w czasie „zbiorowość”, pogranicze kultur, często zmieniające przestrzeń fizyczna w bardzo długim czasie swojego historycznego trwania i w różnych kolejnych koncepcjach. Pogranicze, a więc część peryferyjna, która ciąży ku jakiemuś zewnętrznemu i zmiennemu politycznie, kulturalnemu centrum. Renata Putzlacher wychodząc z zapisków własnej rodziny, ze swoich doświadczeń, rozmyślań i odczuć właśnie ten problem stawia w centrum swych rozważań i twórczości w ogóle.

Włoski pisarz i historyk literatury Claudio Magris stwierdzał kiedyś w czasie jednej 
z dyskusji na temat środkowoeuropejskiej tożsamości, iż jest ona niezwykle złożona i że właśnie owa złożoność wyłoniła $\mathrm{z}$ siebie wiele wielkich dzieł literackich. Nie mogąc bowiem jasno określić własnej indywidualnej tożsamości narodowej i kulturalnej, zdefiniować samego siebie, pisarze tych rejonów zwracać się mieli raczej ku „podmiotowi uniwersalnemu”. Jako szczególne wyróżniki kultury środkowoeuropejskiej Magris wylicza: skłonność do analizy, obronę jednostki przeciw totalitaryzmowi i przeciw wszelkim standaryzującym modelom świata. Wydobywa również znaczenie rozwijającej się na tych terenach, emancypującej się kultury żydowskiej, językowo mocno związanej z niemczyzną.

Do tej grupy utworów pisarzy europejskich aspiruje i oryginalny artefakt doktor Putzlacher-Buchtovej, w którym epicko-liryczny watek $K a$ wiarni Avion, której nie ma przypomina odbiorcy o trudnych dziejach tej części Europy. Autorka pięknie i nienachalnie ukazuje, że jest to teren kultury przejściowej, teren o złożonej i zmiennej tożsamości, reprezentującej raczej „zbiorowość” niż „wspólnotę”. Ze względu na swoją wielokulturowość i wielojęzyczność bowiem poszczególne literatury narodowe tych obszarów ciążyły i ciążą nadal ku własnym centrom kulturowym, własnym tradycjom, choć działo się to $\mathrm{z}$ różną siłą $\mathrm{i}$ intensywnością. Owo ciążenie ku rodzimym dla danego etnikum i języka centrom kulturowym oraz zmienność losów historycznych terytorium powodowały, iż nie mogły tu powstawać jakieś jednorodne dla wszystkich obcujących tu z sobą kultur wzory postrzegania świata czy jednolite wzorcowe typy zachowań, a także podstawowe typy osobowości - basic personality types. Wytwarzała się natomiast osobowość liminalna, którą autorka metaforycznie określiła jako osobę stojąca na moście.

Jakie więc oblicze literatury środkowoeuropejskiej wyłania się z tych urywkowych rozważań, przypomnień i zestawień, scalonych ciepłym liryzmem autorki $W$ kawiarni Avion, której nie ma? Jest to skomplikowane oblicze własnej tożsamości Europy Środkowej, wyrosłej na gruncie specyfiki lokalnych odrębności, ale powiązanej przy tym nieodłącznie z zachodnią literaturą europejską, bowiem jej specyfika środkowoeuropejska, twórczo wchłaniając i w sposób oryginalny przetwarzając wiele zachodnioeuropejskich podniet, odczuć, osiągnięć jest ściśle związana z kodem euroatlantyckim. Jak $W$ kawiarni Avion, której nie ma...

prof. dr hab. Krystyna Kardyni-Pelikánová, DrSc.

Brno, Česká republika

pelikanova.kristyna@seznam.cz 